\title{
History as rhetoric, fable, and literary genre
}

\author{
Alejandro Cheirif Wolosky \\ Museum of natural history, Luxemburg, Luxembourg \\ Email address: \\ alexcheirif@yahoo.com
}

To cite this article:

Alejandro Cheirif Wolosky. History as Rhetoric, Fable, and Literary Genre. International Journal of Literature and arts. Vol. 2, No. 1, 2014, pp. 16-23. doi: 10.11648/j.ijla.20140201.14

\begin{abstract}
This article provides an insight into the notion of history as a literary genre. It argues that in the sixteenth and seventeenth centuries the concept of "history" was mostly employed in its plural form: "the stories" and not "history" were the predominant form of the concept of history. These "stories" were related to the ancient Ciceronian rhetorical and moral tradition of history as Magistra Vitae (history as life's teacher) and were considered part of the so-called belles-lettres or "literature".
\end{abstract}

Keywords: History, Literature, Rhetoric, Fable

\section{Introduction}

In the fifth edition of the Dictionary of the French Academy (Dictionnaire de l'Académie Française), published in 1798, in the entry for the word histoire, written in the singular and feminine form, we find the following definition: "Narrative of actions and events worth of memory." [1] This definition was published for the first time in 1694 and remained unaltered throughout the editions of the eighteenth and nineteenth centuries. It associates the word histoire (history) with the word récit or narration (tale, account) of the events of the past. As shown by the definition of the dictionaries of the French Academy, defining the word histoire (history) as a récit (tale, account) was rather common in the dictionaries published in the nineteenth-century. Already in 1832 G. W. F. Hegel had noted the double meaning inherent in the German word Geschichte (History): "The word Geschichte converges in our language the objective and the subjective: it refers to the account of events as much as to the events themselves; it is no less related to what has happened (Geschehen) than it is to the account of what has happened (Geschichterzählung)." [2] What distinguishes the word Geschichte is that its singular form refers to one unique history: "History". On the other hand, the concept "die historien", written in the plural form, refers to a plurality of "stories": it admits the possibility of several stories. As has been demonstrated by R. Kosselleck in the entry for the word Geschichte / Historie of the lexicon Geschichtliche Grundbegriffe, since the germanization of the Latin word historia in the thirteenth-century, the German language designated the "subjective" aspect of history with the word Historie -- the account or narration of what has happened -and with the word Geschichte its objective aspect: the events of the past themselves. Towards the end of the eighteenth-century, the word Geschichte, derived from the verb geschehen (to occur), merged both meanings into one single word (Geschichte).

The replacement of the concept of "the story" (historien) by "history" (Geschichte) during the nineteenth-century overshadows the fact that, between the sixteenth and the eighteenth-century, the most common use of our concept was not "history" but "the story" (l'Historia Magistra Vitae): not the objectivity of history in its singular form, but rather the subjective aspect of a story -- the account related in a story.

In the French language, the distinction between les histoires (the stories) and l'histoire (history) in the early modern period is rarely a strictly semantic distinction: l'histoire (history) and les histoires (the stories) was used in a somewhat arbitrary manner. It follows that this distinction is, in the case of the French language, an a posteriori demarcation that allows us to distinguish two different concepts (l'histoire and les histoires). These are two clearly discernible concepts and, nonetheless, in the French language, they are not designated by two different words. The same cannot be said about the German language: The distinction between Historie and Geschichte allowed, until the eighteenth-century, to distinguish with a particular concept (Historie) the meaning of a word that, since Cicero, designated all individual stories: the Historia Magistra Vitae. As has been demonstrated by Koselleck, this concept, 
coined by Cicero, was intimately linked to the art of rhetoric: since the speaker alone provided immortality to the related stories. In the course of the sixteenth-century, J. Bodin, who defined history as the exact narration of the actions of the past, derived from this concept, Historia Magistra Vitae, the moral imperative along which the whole life of men must be governed by the sacred laws of history. It is in that very way that history became able to explain the present, to forecast the future and to govern the contingencies of everyday life. It is thanks to history that the present can be readily explained, that the future can be penetrated and that we can acquire very certain indications on what should be suitably pursued or avoided. Nevertheless, for J. Bodin, the exemplary history does not lack method. As it is the case with other sciences, history must sort the historical facts into well-established categories. The historical method consists in disposing methodically the categories of memorable things to be able to draw a variety of examples to regulate our behavior. The function of history, according to J. Bodin, is none other than to be a "life instructor" and a "guide to existence." [3]

M. de Montaigne's judgment of "the stories", which he terms the great souls of better centuries, is somewhat paradoxical: On the one hand, he distrusts these incongruent things. They are, he claims, the subject of impostures: "From this, it occurs that nothing is as firmly believed as that of which we know less about -- what comes from those who tell us such tales as the alchemists, the judiciary prognosticators, the physicians, etc." [4] For this reason, he privileges the eye witness. For him, the only good stories are those that have been written by the same people who conducted the events, or who participated in them.

On the other hand, he is more interested in the judgment than in the story; more intrigued by the moral principles than by the tale" focused more in the moral axioms than in the stories themselves. M. de Montaigne classifies the historians into two categories: the "simple historian" and the "excellent historian". The simple historian doesn't embellish or develop further the tale; he doesn't throw in things of his own. He only assembles the facts, leaving us in their doing "the judgment" -- it is the judgment alone that brings us closer to the truth. It is J. Froissard, so mentions M. de Montaigne, who presents us with the matter of history bare and shapeless, so that each person can profit from it as much as he wants. As for the historians he names "excellent historians", they recount only what is worth being known. More than that, they convey their judgment of the tale, they allow themselves to judge; that is the reason why they confuse the story with their own ingenuity. Yet, M. de Montaigne does not despise the historians deemed "excellent". Quite the opposite, what interests him is not so much the stories themselves but judging them, it is rather what comes from the inside than what has happened on the outside. For this reason, as to the historian deemed "excellent", he adds: "Shall they boldly spread out their eloquence and discourses, shall they judge in their position: but that they also leave us something to judge after them." [5] So, for M. de Montaigne, history is manifold: for some, it is a pure grammatical study, for others, it is the anatomy of philosophy, through which the most obscure parts of our nature can be penetrated.

N. Machiavelli employs the Ciceronian conception of the Historia Magistra Vitae as a guide for political action. Stories are, for Machiavelli, examples of the past that evolve into guides for future political action. Among his recommendations to the prince we find the following: "The prince must choose as guides and models the greatest men of the past." [6] The purpose is to reproduce their glory and their virtue. It is only by imitation that the prince might resuscitate the glory of the greatest men. Other than that, reading the stories of the past allows the prince to avoid the adversities of everyday contingencies. The prince must, as the stories demonstrate, use the favorable moments of fortune in order to institute new governments and put new institutions into place: "Moses, Cyrus, Theseus, and Romulus would not have been able to observe their constitutions had they been unarmed." [7]

The Historia Magistra Vitae occupied a fundamental role in the organization of the academic disciplines as we find it in the ancient Faculté des Arts of the Université de Paris, since the edict of Nantes of 1598 until the expulsion of the Jesuits in 1767. The curriculum of the colleges was composed by grammar, classics (or poetry), rhetoric, and philosophy. It was in particular in the rhetoric class that the students read the orators and historians (Cicero, Livy, Demosthenes, Thucydides, etc.). However, the sum of knowledge -- as demonstrate the school manuals -- rested on the examples of the great men of Antiquity: on the archetypes of virtue that allowed to make out of the profane Antiquity the ground for moral education. It was not about searching the truth, but rather about seeking the "common places": the loci communis. It was beauty and goodness, as showed by the Sophists, which shaped opinions as much as they instilled them. Cincinnatus was the symbol of civics and modesty; Demosthenes that of courage, devoid of the vices that drove to the ruin of the cities; and the Roman Republic was the model of all virtues.

We find throughout the eighteenth-century this Ciceronian conception of history. For example, Rollin, in his Traité des Etudes, defines history as a study of moral and virtue, whose goal is to keep us away from the bad examples and from the vicious custom", as much as to acquaint us with goodness and virtue. Among his stories he alludes to the story of Joseph: Joseph sold by his brothers; driven to Egypt to Potiphar; imprisoned. In the case of Rollin, erudition is not compulsory. What is unavoidable, on the other hand, are the instructions that God, with his conduct of the events, wanted to give us. Rollin does not limit his stories to the sacred stories: in doing so, the universal story of J. B. Bossuet teaches us, in the traditions of the nations, the causes of their rise and fall. The profane stories also provide us with models to embrace virtue. So, for example, the story of Cyrus, the wisest of the 
conquerors and the most accomplished hero allows us to see the qualities that form great men. [8] At the end of the eighteenth-century the abbot G. B. Mably evoked this same conception of history. In his Etude de l'histoire he defines history as the school where you are taught of your duties. It is in history that we find models that accompany virtue and the disdain of all vices. As N. Machiavelli, G. B. Mably makes of history a guide for political action. The past, mirror of the future, allows us to anticipate the mistakes of the present: "In the divisions of the Greeks, in the woes caused by their ambition, you will learn about the mistakes of modern Europe.” [9]

\section{History as Literature: from the Perspective of History}

Where does the early modern conception of history as a literary genre come from? As has been shown by R. Koselleck, this conception of history was formulated, in the seventeenth and eighteenth centuries by two contradictory positions that expressed differently the relation between history and poetry. The first considered the res factae (history) above the res fictae (fiction) because, while the latter lead to deceit and distortion, the res factae are a pure mirror of reality: The truth, according to P. Le Moyne, is the foundation of history. The second position evoked the famous formula of Aristotle, for whom poetry was nobler and more philosophical than history. While history relates only the accounts of the past, poetry expresses verisimilitude and is therefore universal. Poetry is then more "philosophical" and more serious than history, since it speaks of things that are universal, while history speaks of things that are particular. The emergence of history as a literary genre is not a consequence of the triumph or defeat of any of these two postures, but rather their progressive conciliation: as for history, its conciliation with generalities; as for poetry, its conciliation with particularities. In the seventeenth-century, history employed its ancient rhetorical tradition to operate this conciliation. Poetry emphasized the emergence of the Romanesque genre - the bourgeois novel and the emancipation of literature from the formalism of the belles-lettres. This forced history to adapt its pursuit of formalism to the changes that poetry and literature were subjected to. History as a literary genre is therefore, on the one hand, a renewal of its ancient rhetorical tradition. However, as literature liberated itself from the strict rules of the belles-lettres, history's quest for formalism was constraint to adapt to modern literature or to look elsewhere -- in philosophy or in science -- the formalism that it had previously found in its ancient rhetorical tradition.

History as a literary genre in the seventeenth-century is an attempt at formalism that translates in the conciliation of history with the poetic principles of its ancient rhetorical tradition. As has been shown by R. Démoris, two treaties were dedicated to this topic in the second half of the seventeenth-century. The first one is titled "On history" (De
l'Histoire) and was written by P. Le Moyne in 1670. The second appeared in 1677 under the title "History instructions" (Instructions pour l'Histoire). It was written by Pierre Rapin. These two treaties are a response to an epistolary, titled "On the uncertainty of history" (Du peu de certitude qu'il y a dans l'histoire), written by the skeptic F. de la Mothe le Vayer in 1668. In his epistolary, F. de la Mothe seeks to demonstrate that there is no certitude in all that has been told by all the famous historians that we have known so far. The historical disputes regarding different accounts of the same event demonstrate, according to F. de la Mothe, the uncertain reality of historical events. The knowledge of past experiences allowed F. de la Mothe to predict that the historians of the future will also be unable to represent accurately historical events. After a dozen examples of historical uncertainty, of which we may find thousands other examples throughout history, F. de la Mothe concluded that all historical narratives are highly suspicious. F. de la Mothe's historical skepticism is also present in his "Preface to a historical work" (Préface pour un ouvrage historique), where he blames the flaw of human attributes that always meet imprecisions and falsehood. In that sense, history, insofar it is written by men and not by gods, remains on the side of error, even of falsehood. In his Jugement sur les anciens et principaux historiens grecs et latins dont il nous reste quelques ouvrages (Judgment of the principal Greek and Latin historians), he insists on the same idea; historical facts are represented in different manners and in divergent historical narratives. To this problematic must be added the fallible attributes of the human condition. All historians share these human flaws. Plutarch as well as Herodotus, Polybius as much as Phylarchos. Among those human flaws are not only ignorance and barbarism, but also love and hatred, egoism and fear. There is no historian, according to La Mothe, that hasn't been dominated by his passions, of which every legitimate story should be exempted.

What were the answers of the Jesuits P. le Moyne and P. Rapin to the historical skepticism of F. de la Mothe? While attacking the Pyrrhonian skepticism and cartesianism of F. de la Mothe -- which constitute the most manifest danger for Christianity -- they advocate for a restoration of the stylistic formalism of the ancient rhetorical tradition, borrowed from Cicero, in order to provide to the historical narrative its proper epistemological and aesthetical validity. P. le Moyne defines history as "a continuous narrative of true things, written with spirit, with eloquence and judgment, for the instruction of particulars and princes." [10] History is a narrative because it edifies a "tale" or a "story" of the events of the past: the historian is therefore a narrator that must please with his eloquence. However, it is not a narrative of "true things": it is in this particular aspect that it distinguishes itself from the novel and from epic poetry. However, it is due to this same characteristic -- because it tells the truth -- that history is a Magistra Vitae. It follows that, due to its exemplary character, history is a philosophy of the political and social behavior, on which depends the moral guidance of the people and the instruction of the 
princes. The true tale of history is then, for P. le Moyne, superior to poetry's nobility. However, in order to give way to a true tale, it is necessary to dispose of the three beauties of the tale: the transitions, which provide smoothness and affability to the narrative; the circumstances, which render the tale plausible in its rendition of the events; and the motives, which trace the events back to its sources and explain the facts. Yet, the narrative might dispose of harangues -- soliloquies or hyperboles edified by the narrator in order to expose the virtuous eloquence of the orator -- it is in this remodeling of the tale that an authentic work of art comes into being. It is thus in the old rhetorical tradition of history that the tale might aspire to poetry: an epic poem freed of the dungeons of versification.

\section{From the Perspective of Poetry}

The ambiguity of the status of the concept of "literature" in the eighteenth-century is a consequence of a semantic revolution. This revolution is roughly an "interlude" between, on the one hand, the literature defined as belles-lettres -- as they were defined in the Grand Siècle -and, on the other hand, the "emancipated" literature of the nineteenth-century. In the eighteenth-century the res litteraria were subject to a lexical shift. The ancient equivalence between literature and belles-lettres, that of the Grande Siècle, became instable and rare as the French Revolution approached. Literature defined as putting actions into place, according to Aristotle's formula and the classical poetic principles -- the inventio (the choice of a subject), the dispositio (the arrangement of the parts) and the elocutio (the beautification) -- was slowly replaced by a literature emancipated of the formalism of the belles-lettres: "free literature". The poetical and philosophical developments of the late eighteenth-century insinuated the emergence of a new poetry: poetry in search of a new epistemological and aesthetical status. So, at the turning of the century, the poetry of A. W. Schlegel and Novalis, while striving for the totality of knowledge -- art as well as philosophy, science as well as religion -- it did so in a radically new context and meaning as that of the belles-lettres. If A. Furetiere's dictionary, at the beginning of the century, included within the concept of "literature" all arts and sciences -- including physics, geometry, and the solid sciences -- so did the romantic poets of the early nineteenth century. However, for the romantics, "merging" the totality of knowledge into one single concept (literature) did not have the same meaning as it did at the time of the belles-lettres: the epistemological status of literature had changed. In other words, literature as a concept and as a discursive practice had constituted a new paradigm and a new normative system. This conceptual revolution had as a consequence the disruption of the ancient system of poetic representation as it was defined by the treaties of the eighteenth-century (treaties which inspired the definition of the word literature). This classical system of poetic representation was constituted by four fundamental poetic principles. The first principle was "fiction". Fiction was in fact a restoration of the ancient principle, depicted in the Poetics of Aristotle, which makes of all poems a representation or an imitation of an action. Speech was then always linked to an action - as in a mirror - where things and words are fully correlated. The second principle was that of "generality". Every representation belonged to a genre -tragedy, comedy, epic, etc. The genre was defined by the subject represented and not the opposite: action determined speech. The third principle was that of "convenience". The convenience -- natural, moral, historical -- allowed the faithful performance of the action by the adequacy of the means of representation: of the representative triangle that formed the characters, the public and the action represented in a space of public instruction: the theatre. The new poetry of the turning of the century was a reversal of these four poetic principles. The principle of "fiction" was overturned: speech replaced action. "Generality" was contested by the equality of the presented subjects; convenience by the indifference of style. The disruption of the poetic system had as a consequence the triumph of the non-generic genre: the novel. It is the primacy of this new genre that became, at the turn of the century, the model of history as a literary genre.

\section{History as a Fable}

Fable, from the latin fabula, means "discourse" or "tale". J. de la Fontaine defines it as "a small tale that enshrouds a moral under the veil of a fiction." [11] This definition was incorporated in the Dictionnaire de l'Académie Française, in its sixth edition, in 1835, with a small and nonetheless important modification: "Apologue, tale in which a small truth is hidden; a moral under the veil of a fiction." [12] The fourth edition, however, from 1762, provides another definition: "Fable can also be taken in its collective sense to define all the fables of the pagan antiquity." [13] When the concept is employed in this particular sense, as noted the Dictionary of J. Féraud of 1787 , it is not written in the plural but in the singular form: the fable. The fable is then, like history, a "collective singular" that refers to all the fables of the Classical Antiquity. This double meaning of the word fable -- on the one hand, a tale that veils a moral or a small truth, and, on the other hand, a "collective singular" that refers to all the fables of the pagan Antiquity -- expresses a certain duplicity, if not a paradox, constitutive of the concept: on the one hand, the fiction and its falsehood; on the other hand, the moral understood as a "small truth". The dictionary of P. Larousse, in its 1872 edition, enlightens this problematic. P. Larousse defines the fable as a "mythological fiction, an imaginary event attached to the history of a particular religion." [14] He refers in this sense to the Greek fables, the Indian fables, the Scandinavian fables, etc. This distinction of the fable as a false tale and history as a true tale can be traced back to the eighteenth-century. Voltaire, for example, defined the fable simply as "the history of the primitive times." [15] This was the meaning of the fable when $\mathrm{C}$. Rollin said that the tale Herodotus made of the first beginnings of Cyrus resembles 
much more a fable than a history. However, during the seventeenth century, history and the fable were not so far from one another. What characterizes history -- or a story -as well as a fable is not the truth or fiction of the tale but its content -- what J. de la Fontaine names the soul of the apologue. That is why, for J. de la Fontaine, the apologue is not a lie but rather the opposite: a fundamental truth. In rhetorical terms, the soul of the fable is the "common place" -- the locus communis. The apologue is, according to J. de la Fontaine, composed of two parts, of which one we call the body, the other the soul. The body is the fable; the soul is the moral. What characterizes a fable in the seventeenth-century is not its "falsehood", as related by the dictionaries -- it is the fact that this "fiction" concealed a commonly shared and fundamental truth. That is the reason Descartes presents his Discours de la Méthode "as a story, or, if you prefer, as a fable." [16]

How did the fabulists of the seventeenth-century define the fable? In his 1671 preface to his Fables morales et nouvelles, A. Furetière defines the fable as the most ancient thing in the universe of letters. The fables, he says, have their origins in the East. We find them among the Hebrews, the Indians and the Persians before the sciences had expanded into Greece and Italy. All knowledge was then composed of fables, but also of parables, enigmas and hieroglyphs. The fables could well be a way of hiding ancient precepts in fictions in order to insinuate them in a more subtle manner in the spirit of the princes. The bare truth was then too dangerous to be told. The fable, as opposed to dramatic poetry -- which employs the tragic genre to instruct the heroes and comedy to instruct the commons -- is the only literary genre that has been used to instruct the commons and kings alike. Rather than a modern invention, the fables of the seventeenth-century are a restoration of the fables of the Ancients, notably of Aesop and Phaedrus: "We were content with their translation - writes A. Furetière - in all sorts of languages, and in prose, and in verse, and with as many ornaments as imaginable." [17] It was notably J. de la Fontaine who translated them, gathering all the fables of the Ancient poets and orators, and, in doing that, he added great beauty to the originals. We find this same notion of restoration of Antiquity in $\mathrm{N}$. Boileau's La fable et l'allégorie, for whom, in the fables each virtue becomes a divinity. And so, like the poets of the Antiquity, the modern poet amuses himself with thousands of inventions, he ornaments, embellishes, and enlarges the stories. The fable, according to N. Boileau, must borrow the forms and figures of the pagan Antiquity: "Without all these ornaments the verse transmutes into doldrums, the poetry is dead or crawls without vigor; the poet becomes a timid orator, a frigid historian of an insipid fable." [18] Just like with the stories, the tension between the Christian truth and the pagan truth must be reconciled in the name of a same morality, a same fundamental truth concealed behind the body of the fable. Nonetheless, it is not only an aesthetic question: the truth that we find in the moral requires of the beauty of the fable and, inversely, the fable cannot be beautiful without being a hidden fundamental truth. As expressed by N. Boileau: "Nothing is beautiful but the truth, the truth alone and kind; it must govern over all, and even in the fable." [19] It is precisely Jean de la Fontaine who, in his preface to his first collection of fables, pleaded for the complicity of truth and beauty. He found his justification in the Ancients who, with their fables, introduced the sciences among men. Aesop, the wisest man of the ancients, according to J. de la Fontaine, while introducing the ornaments of poetry, invented the singular art of merging beauty and truth in a single fable. We hear therefore that "the Spartan graces are not the enemies of the French muses." [20] Socrates, who thought, like Phaedrus, that fables were the sisters of poetry, composed Aesop's fables in rhyme, and dressed them with the livery of the muses. When Socrates was condemned to death, according to the testimony of Plato, the gods recommended that he spends his last days on musical exercises. However, the only music that pleased him was that where truth and beauty merged into one same harmony. That is why many characters of Antiquity attributed the greater part of these fables to Socrates, the only man who communicated with the gods. The apologues, like the parables, were the way in which the gods handed the truth to men. The truth had spoken to men in parables. That is why Plato, having banned Homer of his Republic, he gave Aesop a quite honorable place. He saw in Aesop's fables a way to educate children on what is good and true and to accustom people to wisdom and virtue.

This complicity between modernity and Classical Antiquity indicates, on the one hand, an association of the two meanings of the word fable (the fable in its singular form and the fables in its plural form), and, on the other hand, it paradoxically subordinates the body to the soul of the fable while, at the same time, employs the body of the fable to achieve a cathartic moment in which beauty and truth are combined.

Yet, it is true, as says J. de la Fontaine, that Aristotle allows only animals in a fable. However, La Fontaine himself warns that this rule is less of necessity as of discretion, because neither Aesop nor Phaedrus, nor any other fabulist adheres to it. Indeed, animals are only present in half of the fables of $\mathrm{J}$. de la Fontaine. What distinguishes the fables, according to la Fontaine, is not the presence of animals -- it would be a mistake to see there the fundamental difference between fables and histories. What distinguishes the fables, notably in the seventeenth-century, and what brings them close to the stories, is their purpose: morality, which none of the fabulists eludes. That is why, for example, J. de la Fontaine warns in the preface of his fables that he didn't want to introduce only animals, but also doctors, philosophers, trees, plants, and many other things. The presence of animals in the fables of the seventeenth-century must be understood as an expression of the seventeenth-century allegorical imagination, as shown by the treaties of physiognomy, such as De Humana Physognomonia by G. della Porta, for whom men and animals are alike because, in men as much as in animals, we 
find their temperament engraved in their morphology: "The properties of animals and their diverse characteristics, says J. de la Fontaine, are expressed in their morphology; as a consequence so is our own, since we are nothing but a sample of what's good and bad in these irrational creatures. When Prometheus wanted to form man, he took the dominating qualities of each beast; out of these different pieces he composed our species; he made what we call the micro-cosmos, and so these fables are nothing but a picture in which each one of us is depicted." [21] In the eighteenth-century the legitimacy of the fables was contested by a new concept: History. The fables, identified more and more with fiction and falsehood, became, according to Voltaire's formula, the history of primitive times. This permitted to delimitate the frontiers of the new History: that of the true representation of things. On the other hand, the fable, rejecting the new field of truth was able to reside freely in the world of the fabulous and the fictitious. Already in 1724, B. Fontenelle traced the origin of fables to the ignorance and barbarism of the first centuries: "It is not possible, he says, not to be frightened while seeing the whole of the ancient history of a population to be nothing but a bunch of chimeras, dreams and absurdities." [22] The great sin committed by the fables of the ancients was not their existence per se, but their "status" -- the fact that they were not taken for what they really are: The fables of the Greeks, according to B. Fontenelle, were not given to us as literature, but as history. The fictitious content of these stories, of these fables, was a consequence of the ignorance and barbarism of the men of the first centuries. However, the fables were not deprived of a certain philosophy. This philosophy consisted in explaining what is unknown in nature with the tools that were available to the savages: "these poor savages, writes Fontenelle, they explained the effects of nature only by the most primitive and palpable things that were available to them." [23] This is how, according to B. Fontenelle, the gods and goddesses were born: the false divinities. As opposed to the fables, composed of the extraordinary effects of the savage world, there was History, a History that understood the regulated order of the universe. The distinction between history and the fables, according to B. Fontenelle, derives from the fact that the former is composed by facts, put in a certain order by reason alone. On the other hand, the fables, while composed of facts as well, they are mingled with the philosophy of the first centuries. It follows then that the fables are some sort of amalgam of facts corrupted by the philosophy of their time. Yet, the time of the fables is not our time. It is the time of the "other": the time of the Ancients. It is the narrative process that adheres to the facts the philosophy of the time -- of the time in which the fable was written. The narrative allows the embellishment of the story while adding ornaments that are false but that are nonetheless plausible. To the extent that History remains on the side of the plausible it continues to be History. It is because of this verisimilitude, according to B. Fontenelle, that despite its false elements, we don't see them as mere fables. However, as soon as the harangues violate the verisimilitude principle, History becomes a mere story or even a fable. The reason that fables are the history of primitive times is, according to $\mathrm{B}$. Fontenelle, the displacement of the verisimilitude principle: "Ancient populations had taken a fancy to these stories where gods and goddesses participated. They were fond of the marvelous; no history was to be narrated without being so embellished. They knew that it might as well not be true. However, in those days it was plausible, and that was enough to give to these fables the quality of Histories." [24] The accurate representation of the past was then, according to B. Fontenelle, a slow and progressive development of reason and philosophy in our civilization. It is mainly due to religion and to common sense that we became disenchanted with these ancient fables. However, these fables found a refuge in art and poetry; it is notably there that the fables found the secret of its necessity. From then on the fables, and the stories with them, changed their epistemological status: they lost their longing for the truth, and since then resided secretly among words and letters in what ended up constituting a new concept: literature.

\section{History as a Literary Genre}

The most symptomatic consequence of these two transformations - on the one hand, the collision of history and literature, and, on the other hand, the emancipation of literature from the belles-lettres - was, at the turn of the eighteenth to nineteenth century, the appearance of the historical novel. "Walter Scott reigned at the time, in London and in Paris" - wrote A. Dumas in his memoirs. [25] History as a literary genre in the first decades of the nineteenth-century, according to the testimony of Stendhal in 1825, arose from Walter Scott's historical novels: "Ivanhoe has made fashionable books like Thierry's and Guizot's" -- wrote A. Dumas. [26] Likewise, H. Martin wrote in 1833 that "the historical novel must be today more than ever the complement of actual history." [27] Indeed, it was this new prose literature, as J. Michelet wrote in his Introduction à l'Histoire Universelle, this shift from mute symbolism to poetry, and from poetry to prose that constituted this new spirit: the "prosaic" spirit of modern French democracy, the "ultimate way of thinking", the most free and the most "humane". [28] In Le Libelliste, H. Martin, alluding to W. Scott, evoked the fundamental elements of this new history: painting. "Drawing back to the sources he gathers the colors that come into sight in order to finish a detailed painting out of that first rough draft; it then becomes a finished poem with each episode of the ensemble unfolded on its canvas." [29] It is precisely W. Scott, as says H. de Balzac in the preface of his Human Comedy, who attempted to paint a face of life, for it was not about telling the story of the "three or four thousand characters that compose a society", it was rather about creating "one or two typical characters."'[30]

What does "the painting of history" actually mean? One 
of the best expositions of this method can be found in the preface to The history of the burgundy dukes of the house of Valois, written by P. de Barante in 1826. In this preface, P. de Barante criticizes what he calls the "typical naïve nature of the French narrator." [31] The French narrator, "pushed by the need of introducing himself into the scene" adds "something" to the story. [32] What is this something? He adds "everything that surrounds him". [33] In doing so he gives "a dramatic physiognomy to the facts that he relates, and to the characters that he represents." [34] The writing of history insinuates the time of the historian in the historical narrative: the color of time. The past as otherness, its rare and different nature, provokes a tension between the narrator and the documents of the past. According to P. de Barante, the historian judges the documents and shows himself superior to his own narration, amused by the performance that he's seen. Yet, how does the historian paint history? Historical knowledge is not accessible to the witness. The latter barely recounts what is accessible to his own eyes. Historical knowledge is not accessible to the erudite either. The erudite is a mere compiler of facts. As soon as they have embraced a large timespan, according to P. de Barante, as soon as they have created this vast enterprise of presenting in a certain order the annals of a nation, the details that give life to history have disappeared; the characters have been erased. How does the historian distinguish himself, according to P. de Barante, from the witness and from the erudite? "With his intimate knowledge of what is alive, of what he's heard about, his animated memories that engrave in his history a certain sympathy with the actions, words and feeling of human beings." [35] That is why the novel, the epic poem, and the tragedy are often more lively to our eyes than the historic tale.

What dispels the historian from his own past is the color of time, the actual spirit of the time. The historian, according to P. de Barante, recounts the events of the past in a moral scale that is different from that of the past. That is why the events or actions of the past present themselves isolated and entirely free, while they were formerly part of the customs of a whole population, and brought forth by the ordinary pace of things. The historian totalizes the otherness of the past. He occupies himself mostly with judging it, and, according to $\mathrm{P}$. de Barante, with translating it to the tribunal of another century: The tale is thus engraved with a color that conforms to nothing in its own time. What must the historian do according to $\mathrm{P}$. de Barante? He must paint rather than analyse. Without it, historical events dry up: chronologies and geographical maps replace the joyful and picturesque nature of the past. By actualizing the past to the language of his own time, the historian "disdains" the past as it really is. Under the influence of W. Scott, P. de Barante attempted to "confer to history the attraction that the historical novel had borrowed from history." [36] He aimed at a true and serious history that could be nevertheless alive: not an imitation of the "language" of the past but an incursion in its spirit, and a restitution of its color. The traces of the present would then disappear. P. de Barante attempted in this way to avoid all judgment, and all expression that comes from the present; quite the contrary, according to P. de Barante, the historian must express the judgments and the expressions of the characters of the past.

The era of history as a literary genre had finally arrived. "We are going through a revolution in the way we read and write history" -- wrote Thierry in 1820. [37] The Faculty of Letters of the new Université de Paris, created by the decree of March 17th 1808 included among the "letters", alongside poetry, eloquence, and Greek literature, an ancient and modern history class. "I think that the time has come in which the public will take a liking in history more than in any other serious reading, maybe it is in the order of civilization" -- so wrote A. Thierry in his Letters on the history of France (Lettres sur l'histoire de France). [38] However, as had done H. de Balzac and A. Dumas before him, he expressed his debt and gratitude to W. Scott. In his first letter, he pledged for a return to the original sources, a work that must begin with scientific work and continue with literary writings. With A. Thierry arose, as has been noted by M. Gauchet, "the historical discipline as we know it." [39] It emerged from the convergence of two traditions formerly separated: documentary erudition and narrative exposition. As had done P. de Barante before him, A. Thierry makes of the tale the essential part of history. For, according to A. Thierry, it is not possible for a historian to narrate without painting, and then to paint properly without narrating. What does "painting" mean, according to A. Thierry? To begin with, it is about allowing the past to enter the scene; to display the events and the characters of history fully alive: "I believe that history must not allow, while painting the different eras of history, out of context dissertations". [40] For A. Thierry historical painting was also about avoiding anachronisms. It was about knowing whether men and things have really been as they are presented to us, and that it is not being falsely transported from the present to the past. It is not a mere coincidence that A. Thierry opposes his historical method to the history of out-of-context dissertations. In his sixth letter, he proposes a history of historical writing. Since the birth of modern national history - according to P. de Barante - three historical methods have been successively followed by historians. The first historical method, which can be traced back to the fifteenth and sixteenth centuries, is a sort of poetic history: it is the history of great battles and gallantry. The second historical method, of the beginning of the seventeenth-century, is a history written in a vernacular and more scholarly language where the facts developed in a more orderly manner. The third and last method is the history of morose meditations, annotations, comments, and out-of-context" dissertations. "That is the progress of modern history - says P. de Barante - this is where it stands today." [41]

\section{Conclusion}

Once literature had definitely emancipated from the formalism of the ancient belles-lettres at the turn of the 
century (eighteenth to nineteenth-century), the historical discourses, and the concept of history itself, took two separate and opposed paths: the first one was a rapprochement towards free literature. The historical novel and history as a literary genre from the beginning of the nineteenth-century was the result of this rapprochement. The second path was that of a constant search of formalism. This was a response to the exhaustion of the ancient rhetorical tradition of the Historia Magistra Vitae. Since the sixteenth-century, the historical narrative of the Historia Magistra Vitae had acquired a certain degree of formalism due to its ancient rhetorical tradition. However, since the end of the eighteenth-century, with the crisis of the ancient rhetorical tradition, history had to adapt itself to a new discursive reality. The conceptual distinction between "history" and "literature" distinguishes two distinctly opposed paths: on the one hand, history as a literary genre, a history relatively free of any formalism, and which survived in the plural form "les histoires" (the stories). On the other hand, a constant search for formalism. This had as a consequence the emergence of two new discursive practices at the middle of the nineteenth-century: the philosophy of history and the science of history. It became possible to anticipate the end of history as rhetoric, fable, and literary genre.

\section{References}

[1] Dictionnaire de l'Académie française, Paris: J. J. Smits, 1798, vol. I, p. 689

[2] G. W. F. Hegel, Philosophie der Geschichte, Leipzig: Lasson, 1911, p. VIII.

[3] J. Bodin, La méthode de l'histoire, Paris: Les belles lettres, 1941, p. XXXVIII.

[4] M. Montaigne, Essais, Paris, Firmin Didot Frères, 1854, p. 67.

[5] Idem.

[6] N. Machiavelli, Il Principe, Milan, Einaudi, 1972, p. 16.

[7] Idem.

[8] C. Rollin, Traité des Etudes, Paris: Firmin Didot frères, 1863), vol. 1, p. 164-165.

[9] G. Mably, De l'étude de l'histoire, in Oeuvres complètes, Lyon: Dellamollière, 1792, XII, p. 10.

[10] P. Le Moyne, De l'Histoire, Paris: Louis Billaine, 1670, p. 98.

[11] J. Fontaine, Fables, Tours: Alfred Mame et Fils, 1897, p. XIII.

[12] Dictionnaire de l'Académie française, Paris: Vve B. Brunet, 1825, I, p. 705.

[13] Dictionnaire de l'Académie française, Paris: Vve B. Brunet,
1762, p. 348.

[14] P. Larousse, Grand dictionnaire universel du XIXe siècle, Paris: J. J. Smits, 1872, VIII, p. 4-5.

[15] Voltaire, Essai sur les mœurs, in CEuvres de Voltaire, Paris: Werdet et Lequien fils, 1829, XV, p. 119.

[16] R. Descartes, Discours de la méthode, Paris: Ernest Flammarion, 1938, p. 5.

[17] A. Furetière, Fables morales et nouvelles, Paris: Louis Billaine, 1671, p. 10.

[18] N. Boileau, Art poétique, Paris: Garnier Frères, 1861, 201.

[19] Idem.

[20] J. Fontaine, Op. Cit., p. X.

[21] Ibid., p. XV.

[22] B. Fontenelle, De l'origine des fables, Paris: Chapagnac, 1825, IV, p. 294.

[23] Ibid., p. 297.

[24] Idem.

[25] A. Dumas, Mes Mémoires, Paris: Lafont, 1898, vol. II, p. 362.

[26] Idem.

[27] H. Martin, Le libelliste, Paris: Eugène Renduel, 1833, p. $\mathrm{X}$.

[28] J. Michelet, Introduction à l'Histoire Universelle, Paris: Hachette, 1849, p. 49.

[29] H. Martin, Op. Cit., p. X.

[30] H. Balzac, Avant-propos de la Comédie humaine, Paris : J. Davies 1842, p. 7-8.

[31] P. B. Barante, Histoire des ducs de Bourgogne de la maison de Valois, Paris: Ladvocat, 1826, p. 2.

[32] Idem.

[33] Idem.

[34] Ibid., p. 9-10.

[35] Ibid., p. 12-13.

[36] Ibid., p. 40-41.

[37] A. Thierry, Lettres sur l'histoire de France, Paris: J. Tessier, 1842 , p. 84.

[38] Idem.

[39] M. Gauchet, "Les Lettres sur l'histoire de France d'Augustin Thierry," P. Nora (ed.), Les lieux de mémoire, Paris: Gallimard, 1986, vol. II, p. 280.

[40] A. Thierry, Op. Cit., p. 76-78.

[41] Ibid., p. 80. 